\title{
piRNAs: nature, biogenesis, regulation, and their potential clinical utility
}

\author{
Emilio Eslava-Avilés ${ }^{1,2}$ and Francisco Arenas-Huertero ${ }^{2 *}$ \\ ${ }^{1}$ Programa de Posgrado en Ciencias Biológicas, Facultad de Medicina, Universidad Nacional Autónoma de México; '2Laboratorio de Investigación \\ en Patología Experimental, Hospital Infantil de México Federico Gómez. Mexico City, Mexico
}

\begin{abstract}
RNAs that interact with PIWI (P-element Induced Wimpy) proteins, called piRNAs, were discovered in 2006. Considered the "guardians of the genome," piRNAs were first described in germ cells of Mus musculus and Drosophila melanogaster. Since then, studies have focused on elucidating their origin, biogenesis, and mechanisms of action. Today, we know some of the molecules that participate in these processes, but the nature of the molecular processes that they perform remains largely unknown. However, recent studies have demonstrated that both the piRNAs and their associated proteins are also expressed in somatic cells, suggesting that their scope of action is much greater than initially thought. In addition, their union to PIWI proteins generates a silencing complex that represses the transcriptional and post-transcriptional expression of repeated sequences, including elements known as "transposables". Finally, a recent discovery revealed that this complex could modulate the silencing of specific messenger RNAs (mRNA) necessary for cell regulation. The regulatory function that piRNAs perform in various cellular processes has led to a diversification in their study concerning various diseases, including cancer, where there are indications of their potential function as diagnostic tools, biomarkers for prognoses, and future therapeutic targets. Recently, changes in piRNAs expression have been observed in diseases related to air pollution exposition, such as respiratory diseases.
\end{abstract}

Keywords: piRNA. Non-coding RNA. Biomarkers. Epigenetics. Gene silencing.

\section{piRNAs: naturaleza, biogénesis, regulación y utilidad clínica potencial}

\section{Resumen}

Los RNA que interactúan con las proteínas PIWI (P-element Induced Wimpy), conocidos como piRNA, fueron descubiertos en 2006. Desde entonces, los estudios se han enfocado en dilucidar su origen, biogénesis y mecanismos de acción. En la actualidad se conocen algunas de las moléculas que participan en estos procesos. Sin embargo, los procesos moleculares que estas llevan a cabo aún se desconocen. Considerados como los "guardianes del genoma», los piRNA inicialmente se describieron en células germinales de Mus musculus y Drosophila melanogaster, pero los estudios recientes han demostrado que tanto los piRNA como sus proteínas asociadas se expresan también en células somáticas, lo que sugiere que la acción de los piRNA es mayor de lo que antes se pensaba. Además, su unión con las proteínas PIWI genera un complejo de silenciamiento que reprime la expresión de manera transcripcional y postranscripcional de secuencias repetidas,

Correspondence:

*Francisco Arenas-Huertero

E-mail: farenashuertero@yahoo.com.mx

Available online: 17-09-2021

Date of reception: 23-06-2020 Date of acceptance: 01-12-2020 DOI: 10.24875/BMHIM.20000185
Bol Med Hosp Infant Mex. 2021;78(5):432-442

www.bmhim.com 1665-1146/@ 2020 Hospital Infantil de México Federico Gómez. Published by Permanyer. This is an open access article under the CC BY-NC-ND license (http://creativecommons.org/licenses/by-nc-nd/4.0/). 
incluyendo elementos conocidos como «transponibles». Por último, un descubrimiento ha demostrado que este complejo puede modular el silenciamiento de ciertos RNA mensajeros necesarios para la regulación celular. La función reguladora de los piRNA en múltiples procesos celulares ha contribuido a la diversificación de su estudio en diferentes enfermedades, incluyendo el cáncer, en el que hay indicaciones de su potencial función como herramientas de diagnóstico, biomarcadores de pronóstico y, en un futuro, dianas terapéuticas. Recientemente se han observado cambios en la expresión de piRNA en enfermedades relacionadas con la exposición a contaminantes ambientales, como las enfermedades respiratorias.

Palabras clave: piRNA. RNA no codificantes. Biomarcadores. Epigenética. Silenciamiento génico.

\section{Discovery of a new class of small RNAs}

Our genome codifies hundreds of genes responsible for a myriad of cellular functions. The regulation of the levels of expression of these genes is crucial for development and homeostasis ${ }^{1}$. Around $80 \%$ of the human genome has been transcribed, but only $2 \%$ codifies for proteins. One result of the transcription process of genomes is the production of thousands of non-coding RNAs (ncRNAs) ${ }^{2}$. While the number of ncRNAs in the human genome is unknown, transcriptomic and bioinformatic studies suggest that there may be thousands of them ${ }^{2}$. ncRNAs are classified into two types: long non-coding RNAs (IncRNAs), which have a length greater than 200 nucleotides, and small non-coding RNAs (sncRNAs), whose length is 20-35 nucleotides ${ }^{3}$. The most widely studied sncRNAs are microRNAs (miRNAs) and small interference RNAs (siRNAs). In contrast, due to their recent discovery, the PIWIassociated small RNAs (piRNAs) have not been studied in depth at present ${ }^{4}$.

Both siRNAs and miRNAs associate with the Argonaute family of proteins to perform their functions and act as guides that regulate mRNAs stability, protein synthesis, chromatin organization, and genome structure ${ }^{5,6}$. The Argonaute family is divided into two sub-families of proteins: Argonaute (AGO) and PIWI (P-element Induced Wimpy) ${ }^{1}$. The proteins of the PIWI sub-family participate predominantly in specific events of the germinal line. However, the initial study on the Drosophila gene PIWI determined that its germline function depends on somatic cells of the gonad $^{7}$, although the functions of this family and the nature of the piRNAs that serve as guides were unknown then.

Four independent research groups discovered the piRNAs ${ }^{8-11}$. They were initially isolated from total RNA extracted from mouse testicles. The first observation in a gel stained with ethidium bromide $^{9}$ or SYBR gold 8 revealed a group of small RNAs approximately 28-32 nucleotides long. These RNAs abundance in the testicle led to speculation about their association with the PIWI subfamily of proteins, given that these proteins have been well documented for their essential roles in germline development and gametogenesis on various animal models ${ }^{1,12,13}$. Three PIWI proteins (MIWI/PIWIL1, MIWI2/PIWIL4, and MILI/PIWIL2) are found in mice and have essential roles in spermatogenesis, each of them showing a unique expression pattern ${ }^{14}$, although the expression of MIWI and MILI differs. Initial studies showed that MILI protein is expressed from the mitotic stage to the pachytene phase of the meiotic stage. Meanwhile, MIWI is expressed from the middle stage of the pachytene phase to the formation of the early spermatids. The expression of both is observed in the middle stage of the pachytene phase ${ }^{15}$.

Based on this knowledge, immunoprecipitation ${ }^{8}$ assays were conducted to determine their dependence on MIWI. Findings showed that the piRNAs bonded to MIWI but not to AGO2. Meanwhile, assays with MIWI knockout mice showed that the expression of these piRNAs decreased. These results suggest that the expression of this new class of RNAs is dependent on MIWI. For this reason, they were denominated PIWIinteracting RNAs (piRNAs) ${ }^{9}$. Similar studies that explored the association of MILI with this new class of small RNAs observed RNAs of 26-28 nucleotides associated with $\mathrm{MILI}^{7}$. These findings indicated two classes of piRNAs: the first, with a length of 28-32 nucleotides, associated primarily with MIWI, and the second, with a length of 26-28 nucleotides, associated with MILI.

Upon characterizing these RNAs in greater detail, findings revealed that piRNAs preferred uracil in the first position ${ }^{8}$ and were distributed irregularly along the chromosomes. The piRNAs were found to be codified as follows: $17.6 \%$ in chromosome $17 ; 11.6 \%$ in chromosome $5 ; 10.7 \%$ in chromosome 4 ; and $10.2 \%$ in chromosome 2. Only two piRNAs were found in the $X$ chromosome, and almost none in chromosomes 1, 3, 16,19 , and $Y^{9}$. Other observations showed that the vast majority of piRNAs $(96 \%)^{8}$ formed groups in short genomic loci from $<1 \mathrm{~kb}$ to $>100 \mathrm{~kb}$ in size that contained between 100-4500 piRNAs. These groups are known as "clusters"". 


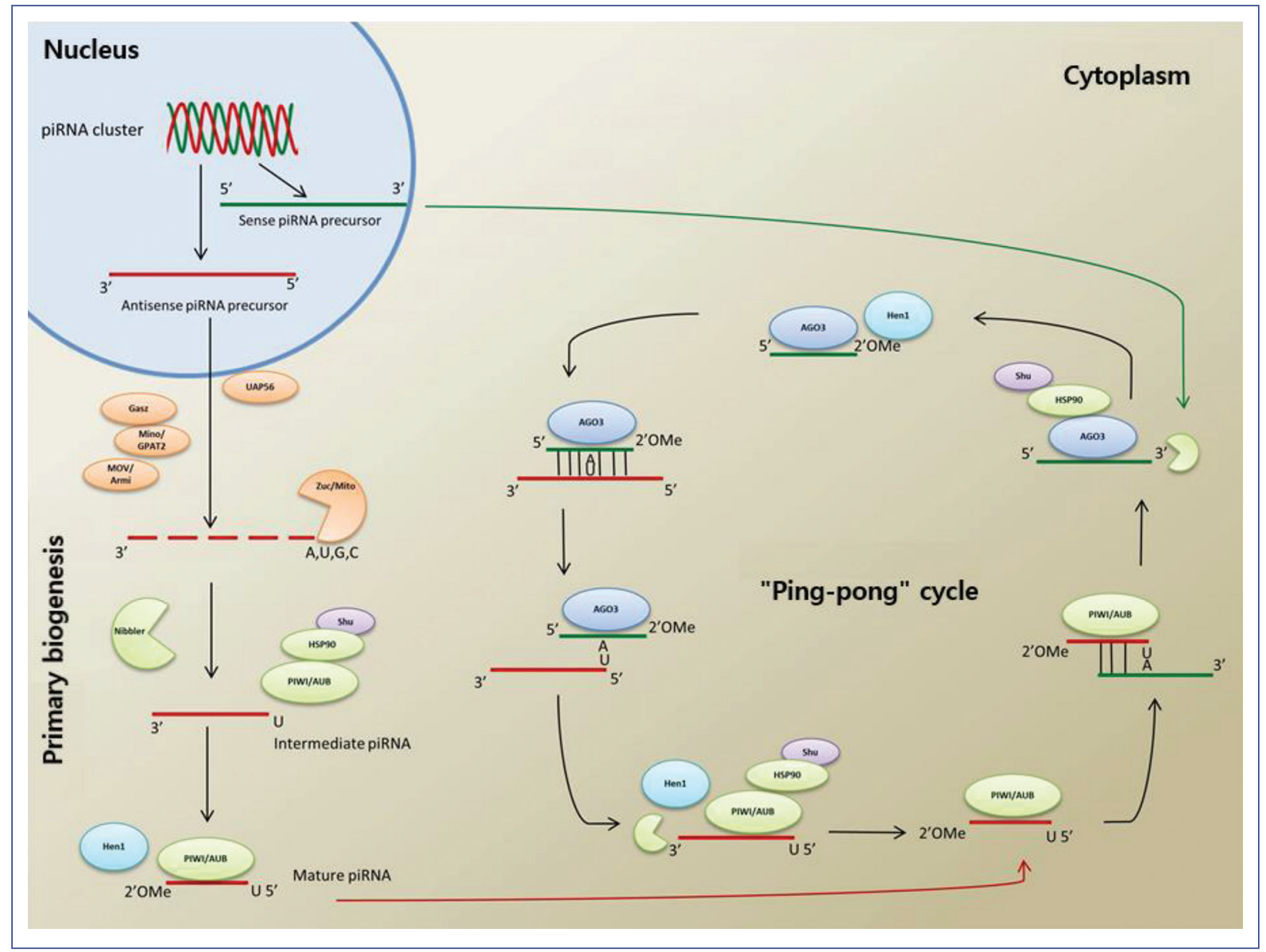

Figure 1. Processing of piRNAs, including primary and secondary biogenesis (ping-pong cycle), and the known molecules that participate in each step.

\section{Processing of piRNAs}

The characteristics and functions of the biogenesis of piRNAs have been studied principally in Drosophila melanogaster, Caenorhabditis elegans, and Mus musculus ${ }^{16,17}$. In contrast to miRNAs and siRNAs, whose biogenesis depends on Dicer and Drosha enzymes to convert their double-stranded precursors into small functional RNAs, piRNAs originate from one sole RNA strand that does not need Dicer or Drosha enzymes. However, piRNAs require an alternative type of processing composed of two pathways: the primary processing pathway and the secondary "ping-pong cycle" (Figure 1) 5,18,19.

\section{Primary biogenesis}

piRNAs come from protein-coding genes, clusters, active transposable elements, IncRNAs, transference RNAs, and small nucleolar RNAs ${ }^{20-24}$. The precursors of single-stranded piRNAs are transcribed and processed to generate intermediate piRNAs. Later, they are transported through the nuclear envelope to processing sites that reside in the cytoplasm ${ }^{25}$. It is believed that their processing in the germinal cells takes place in multiprotein, perinuclear structures called "nuages," or chromatid body, and that delivery of the transcribed piRNAs from the clusters to the processing sites requires the DEAD-box helicase associated with U2AF65 (UAP56, also called Hel25E) ${ }^{26,27}$. In contrast, in somatic cells of ovaries and testis, the production of piRNAs is performed in structures called $\mathrm{Yb}$ bodies. These structures are frequently associated with mithocondria ${ }^{27}$.

Intermediate piRNAs are processed at their 5 ' end by the Zucchini/MITOPLD nucleases in D. melanogaster and M. musculus following their exportation to the cytoplasm ${ }^{28-30}$. Additional observations have found that primary biogenesis in these organisms depends on the 
function of other conserved factors, such as Minotaur (Mino)/GPAT2 and Gasz ${ }^{31,32}$. Also, helicase MOV10L1 (mice homolog of Armitage in Drosophila) is associated with the first cleavage step of piRNA processing, and its function has been related to remodeling secondary structures of those precursors ${ }^{33,34}$. Interestingly, all these proteins, except Armi/MOVO10L1, are localized in the external mitochondrial membrane, suggesting an essential function of mitochondria in the primary processing of piRNAs ${ }^{32,35-39}$.

Intermediate piRNAs bind to the PIWI proteins, a union that requires the Heat shock 90 protein (Hsp90) and the cochaperone Shutdown (Shu) $)^{40-42}$. The current model of the biogenesis of piRNAs suggests that the characteristic size of mature piRNAs is a consequence of the union of intermediate piRNAs with PIWI proteins, followed by clipping performed at their 3' ends by the exonuclease Nibbler ${ }^{43}$.

One report suggests that the $\mathrm{Yb}$ protein with Tudor domains binds directly to intermediate piRNAs via its $\mathrm{N}$-terminal domain and shows homology with the DEAD-box helicase ${ }^{44}$. Since germinal cells do not possess $\mathrm{Yb}$ bodies, their function is probably carried out by two homologs known as Brother of $\mathrm{Yb}(\mathrm{BoYb})$ and Sister of $\mathrm{Yb}(\mathrm{SoYb})^{44}$. Vreteno, another protein with Tudor domains, is essential for the biogenesis of piRNAs in germinal and follicular cells by enabling the correct localization of the PIWI proteins ${ }^{20,42,44-45}$.

In the final step, Hen1 methylates the intermediate piRNAs associated with PIWI at their 3' ends to generate mature piRNAs ${ }^{1,46}$. It appears that this modification is naturally protective since it is found in the majority of the sncRNAs that guide the Argonaute proteins to their target sequences via an almost perfect complementarity to produce the clipping of the transcribed target ${ }^{43,47-48}$.

\section{Secondary biogenesis}

Alternatively, mature piRNAs can act as guides for the generation of secondary piRNAs. Secondary biogenesis, first described in $D$. melanogaster and known as the ping-pong cycle ${ }^{25}$, constitutes an adaptive amplification pathway of piRNAs and initiates the degradation of the target elements and the transposons mRNA through post-transcriptional silencing ${ }^{25}$. Primary piRNAs, which typically begin their 5 ' end with uridine (1U) and are bonded to Aubergine (AUB), show complementarity with ten nucleotides of the secondary piRNAs that usually contain adenosine in position $10(10 \mathrm{~A})$ and are bonded to Argonaute $3(\mathrm{AGO} 3)^{27}$. This complementarity modulates the amplification that generates new secondary piRNAs, which occurs in the form of a pingpong cycle between the sequences associated with AGO3 and $\mathrm{AUB}^{27,49,50 .}$

The antisense primary piRNAs from clusters associate with AUB and detect and clip RNA transcripts to produce the 5' end of new sense piRNAs. After binding to AGO3, this compound recognizes and clips the transcripts from clusters, thus generating more antisense piRNAs with sequences similar or identical to the original piRNA, which can bind again to AUB to complete the ping-pong cycle $25,51,52$. The piRNAs generated in this cycle adapt to the target through a variation in their sequence ${ }^{53,54}$. This pathway leads to a target-dependent amplification of piRNAs and the expansion of diverse piRNA sequences ${ }^{46,55}$.

A recent study showed that the ping-pong cycle could function independently of Zucchini used in piRNA processing $^{56}$. In the absence of Zucchini, a piRNA ${ }^{5}$ ' is typically generated via slicing, but its corresponding 3 ' end is modified by Nibbler (Figure 1).

\section{Regulation of genic expression}

The interaction of piRNAs with the proteins of the PIWI sub-family generates the formation of a ribonucleoprotein known as the piRNA-induced silencing complex (piRISC), which can recognize and silence complementary sequences at the transcriptional and post-transcriptional levels ${ }^{57,58}$.

\section{Transcriptional silencing}

Various studies have analyzed the role of PIWI proteins in transcriptional silencing in $D$. melanogaster, and some have demonstrated that the nuclear localization of the piRISC complex is necessary for the silencing of transposable elements ${ }^{59}$. A loss of PIWI proteins decreases the H3K9me3 mark (trimethylation of the lysine 9 of the $\mathrm{H} 3$ histone) and increases the binding of Pol II in the transposable element promoters ${ }^{16,60}$. Together, these findings suggest a model for transcriptional silencing in which PIWI translocates to the nucleus by interacting with the transcripts, leading to a heterochromatinic conformation and transcriptional repression ${ }^{61}$. Transcriptional silencing by piRISC also requires the GTSF-1/Asterix protein, which interacts directly with PIWI and is necessary for establishing the H3K9me3 chromatinic mark ${ }^{62,63}$. The union of Panoramix (Panx, also called Silencio) to PIWI has also been identified, which helps in forming heterochromatin through methyltransferase H3K9 Eggless and its 
co-factor, Windei ${ }^{64,65}$. Recent studies ${ }^{66}$ have shown that SUMO E3 ligase Su(var)2-10 induces local sumoylation, leading to the recruitment of the Eggless/Windei complex. These results indicated a novel SUMO pathway in piRNA-related transcriptional regulation.

The piRISC complex generally recruits the heterochromatin protein 1 (HP1) (which binds to methylated DNA) to maintain and propagate epigenetic silencing and $\mathrm{Su}(\mathrm{var}) 3-9$, a methyltransferase histone (HMT) responsible for the methylation of lysine 9 in histone 3 (H3K9) in specific genomic targets; in this way, it blocks transcription $^{30,67,68}$. In addition, the lysine-specific demethylase 1 (Lsd1) removes the dimethylation of the lysine 4 on histone 3 of the promoter region of the transposons, thus promoting its efficient suppression ${ }^{69}$. Other observations show that the Maelstrom group of proteins (Mael) is necessary for the inhibition of Pol II, and its RNase activity seems dispensable for transposon silencing 60,70 .

In mammals, in contrast, transcriptional silencing is performed by modifying the histones and DNA methylation, which is one of the primary mechanisms in piRNAs silencing properties ${ }^{71-73}$. The piRNA/PIWI complex recruits DNA methyltransferase (DNMT) to methylate genic CpG sites, altering transcriptional activity ${ }^{30}$. In mice, the two PIWI proteins MILI and MIWI are required for DNA methylation of transposable elements ${ }^{73}$. In the testicles of mice embryos, MIWI2 enters the nucleus through interaction with MILI to promote the establishment of methylation at $\mathrm{CpG}$ sites of the transposons $\mathrm{DNA}^{71-74}$. Studies have also observed that the pingpong cycle continues in mutants of MIWI2, while MILI performs the methylation of DNA via a mechanism that is independent of $\mathrm{MIWI}^{75}$. A recent study identified a protein associated with MIWI2 (SPOCD1) required for piRNA-guided transposable elements methylation and silencing ${ }^{76}$. This study provided the first mechanistic insight into mammalian piRNA-directed methylation. Despite all these findings, the cascade of events leading to transcriptional silencing in mammals is not yet understood in detail.

\section{Post-transcriptional silencing}

The clipping capacity of the piRISC complex contributes not only to the amplification of piRNA production but can also effectuate the post-transcriptional silencing of transposons ${ }^{77}$. Various studies have demonstrated that this post-transcriptional control is not unique to the RNAs of transposons but also participates in regulating other RNAs, such as mRNA, transcribed pseudogenes, and IncRNAs ${ }^{78-80}$. The post-transcriptional regulation of mRNAs requires the insertion of transposable elements related sequences into mRNA untranslated regions (UTR), the production of piRNAs from genes with similar sequences (pseudogenes), or low complementarity-based targeting of mRNAs with piRNAs produced from transposable elements or repeated sequences ${ }^{81}$.

An increasing number of noncanonical post-transcriptional mechanisms for piRNAs, besides transposon silencing, have been reported in flies, mammals, and other species ${ }^{25,82-90}$.

In fly testicles, which led to the discovery of piRNAs, the Stellate gene linked to the $X$ chromosome is suppressed by a pseudogene in the $Y$ chromosome called $\mathrm{Su}(\mathrm{Ste})^{91}$. In the absence of Su(Ste), the product of the Stellate gene accumulates to form a crystalline structure in the spermatocytes that causes infertility. The $\mathrm{Su}(\mathrm{Ste})$ locus produces piRNAs whose target is the mRNA of Stellate for its later degradation ${ }^{91}$. Significantly, $70 \%$ of the piRNAs associated with AUB in fly testicles are Su(Ste) piRNAs ${ }^{83}$.

In a related aspect, piRNAs associated with MIWI in mammals are responsible for eliminating mRNA in mouse elongating spermatides ${ }^{86,92}$. These piRNAs form a complex with the CAF1 protein and select their target mRNA by partial complementarity at the 3' UTR end, thus promoting their deadenylation and degradation ${ }^{30,86}$.

Observations show that some PIWI proteins are localized to $\mathrm{P}$ bodies or co-localized with components of those bodies ${ }^{93,94}$. A study conducted with ovaries of $D$. melanogaster demonstrated that a small fraction of AUB is found in $P$ bodies and that the transposons transcripts are localized to $\mathrm{P}$ bodies in an AUBdependent manner ${ }^{95}$. Thus, the components of $P$ bodies may contribute to the degradation of the transcripts that are targets of AUB. Similarly, studies showed that MIWI2 is also localized in P bodies ${ }^{96,97}$, but this effect is not seen on mice deficient in piRNAs biogenesis ${ }^{98}$. This finding suggests that piRNAs are necessary for the localization of MIWI2 to P bodies. To date, these findings are still valid ${ }^{14}$ (Figure 2).

\section{Alterations in piRNAs expression and associated diseases}

Diverse studies have demonstrated that alterations in piRNAs expression can either promote or inhibit the development of diverse diseases, especially certain types of cancer, including breast, gastric, lung, 


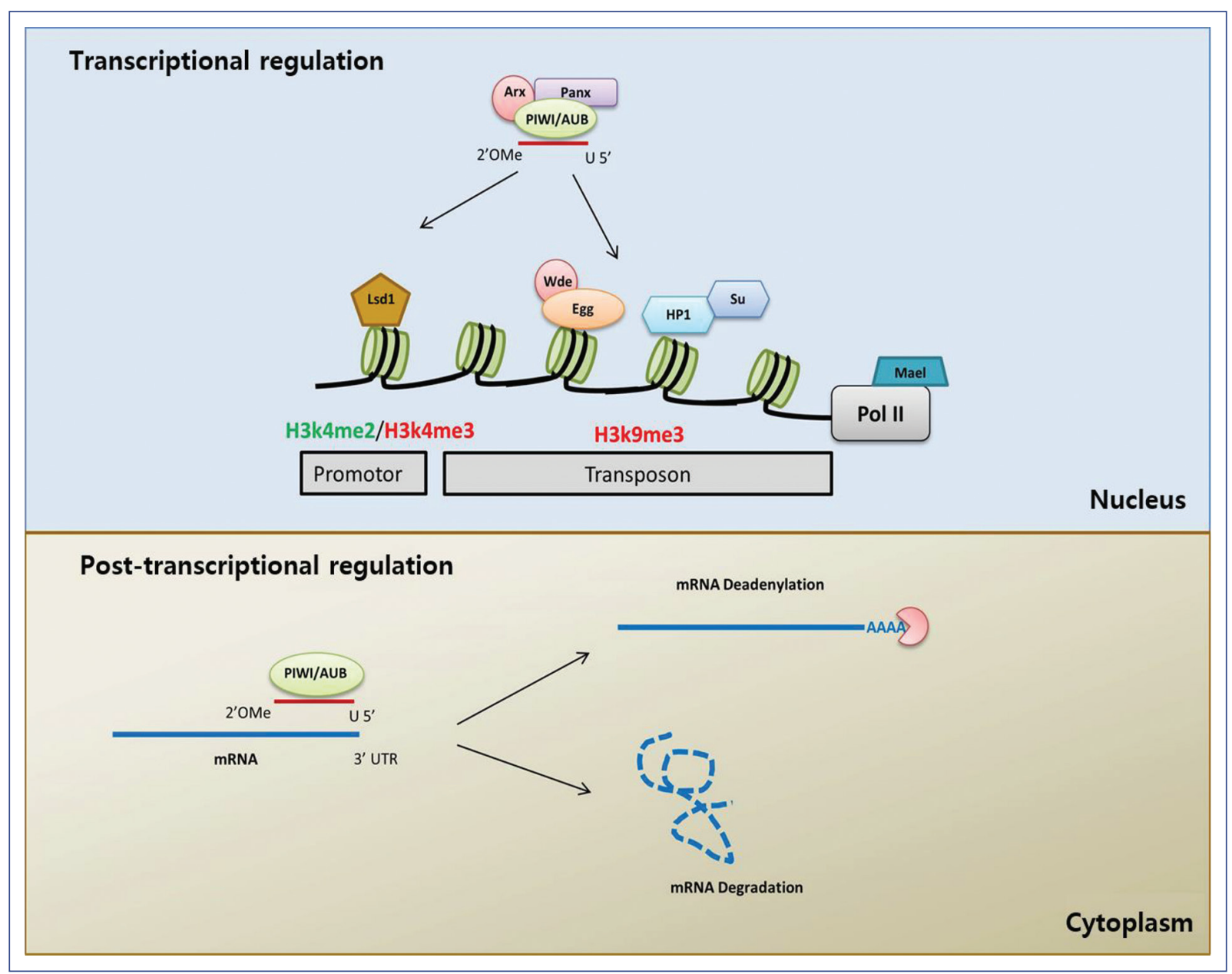

Figure 2. Transcriptional and post-transcriptional regulation performed by the piRNA-induced silencing complex (piRISC) complex, the main molecules that intervene, and how they act on their targets (histones and DNA in transcriptional regulation, mRNA in post-transcriptional regulation).

prostate, colorectal, renal, and bladder cancer, and multiple myeloma (Table 1) $80,99-110$. However, research on piRNAs and their participation in diseases unrelated to cancer, such as respiratory ailments, is scarce.

\section{Respiratory diseases and piRNAs}

Air pollution is an ongoing challenge for humans because various epidemiological studies associate exposure with adverse effects on health-especially on the pulmonary system-including pulmonary inflammation, more susceptibility to respiratory infections, and increased risks of cancer, asthma, and chronic obstructive pulmonary disease (COPD). Numerous recent studies have associated changes in the expression of ncRNAs with the development and progression of these diseases ${ }^{111-122}$. Most studies have focused on analyzing IncRNAs and miRNAs, while only a few have examined the changes in the expression of piRNAs in these diseases. One study used bronchial smooth muscle cells from patients with asthma and healthy subjects $^{123}$. Observations showed a differential expression ( $F C \geq 1.3, p<0.05$ ) of five piRNAs (DQ596390, DQ597484, DQ595186, DQ582264, DQ597347) that could be employed as potential markers of asthma.

Another study evaluated the expression of small RNAs in CD4 T lymphocytes by sequencing ${ }^{124}$. Their findings showed that $12.3 \%$ of the sequences obtained corresponded to piRNAs. Those authors validated the expression of one piRNA (DQ570728) by RT-qPCR (FC $\geq 1, p<0.05)$ and northern blot and then evaluated its function by over-expression in CD4 T lymphocytes to test its effect on cytokines. They observed that DQ570728 significantly reduced $(F C \geq 1, p<0.05)$ the 
Table 1. Research showing piRNAs differential expression in different types of cancer and their potential clinical utility

\begin{tabular}{|c|c|c|c|c|}
\hline piRNA & Type of cancer & Expression & Potential clinical utility & Reference \\
\hline piR-4987 & \multirow[t]{5}{*}{ Breast cancer } & High & Diagnostic tool & \multirow[t]{4}{*}{ Huang et al. ${ }^{99}$} \\
\hline piR-20365 & & High & Prognosis biomarker & \\
\hline piR-20485 & & High & Prognosis biomarker & \\
\hline piR-20582 & & High & Prognosis biomarker & \\
\hline piR-36712 & & Low & $\begin{array}{l}\text { Prognosis biomarker/ } \\
\text { therapeutic target }\end{array}$ & Tan et al. ${ }^{80}$ \\
\hline piR-651 & \multirow[t]{4}{*}{ Gastric cancer } & Low & Diagnostic tool & \multirow[t]{2}{*}{ Cui et al. ${ }^{100}$} \\
\hline piR-823 & & Low & Therapeutic target & \\
\hline piR-41927 & & High & $\begin{array}{l}\text { Diagnostic tool/ } \\
\text { prognosis biomarker }\end{array}$ & \multirow[t]{2}{*}{ Lin et al. ${ }^{101}$} \\
\hline piR-38581 & & High & $\begin{array}{l}\text { Diagnostic tool/ } \\
\text { prognosis biomarker }\end{array}$ & \\
\hline piR-651 & \multirow[t]{5}{*}{ Lung cancer } & High & $\begin{array}{l}\text { Diagnostic tool/ } \\
\text { prognosis biomarker }\end{array}$ & Li et al. ${ }^{102}$ \\
\hline piR-34871 & & High & Diagnostic tool/ therapeutic target & \multirow[t]{4}{*}{ Reeves et al. ${ }^{103}$} \\
\hline piR-52200 & & High & Diagnostic tool/ therapeutic target & \\
\hline piR-35127 & & Low & Diagnostic tool/ therapeutic target & \\
\hline piR-46545 & & Low & Diagnostic tool/ therapeutic target & \\
\hline piR-651 & \multirow[t]{2}{*}{ Prostate cancer } & High & Therapeutic target & \multirow[t]{2}{*}{ Öner et al. ${ }^{104}$} \\
\hline piR-823 & & High & Therapeutic target & \\
\hline piR-18849 & \multirow[t]{4}{*}{ Colorectal cancer } & High & $\begin{array}{l}\text { Diagnostic tool/ } \\
\text { prognosis biomarker }\end{array}$ & \multirow[t]{3}{*}{ Yin et al. ${ }^{105}$} \\
\hline piR-19521 & & High & $\begin{array}{l}\text { Diagnostic tool/ } \\
\text { prognosis biomarker }\end{array}$ & \\
\hline piR-17724 & & High & Diagnostic tool & \\
\hline piR-1245 & & High & Therapeutic target & Weng et al. ${ }^{106}$ \\
\hline piR-32051 & \multirow[t]{5}{*}{ Renal cancer } & High & Prognosis biomarker & \multirow[t]{3}{*}{ Li et al. ${ }^{107}$} \\
\hline piR-39894 & & High & Prognosis biomarker & \\
\hline piR-43607 & & High & Prognosis biomarker & \\
\hline piR-34536 & & Low & Prognosis biomarker & \multirow[t]{2}{*}{ Zhao et al. ${ }^{108}$} \\
\hline piR-51810 & & Low & Prognosis biomarker & \\
\hline piR-594040 & Bladder cancer & Low & Diagnostic tool/ therapeutic target & Chu et al. ${ }^{109}$ \\
\hline piR-823 & Multiple myeloma & High & Prognosis biomarker/ therapeutic target & Yan et al. ${ }^{110}$ \\
\hline
\end{tabular}

expression of IL-4 and IL-5, which are involved in the development and maintenance of Th2 lymphocytes. They further analyzed the clinical importance of these results by evaluating the expression of DQ570728 and
IL-4 in the serum of patients with asthma and healthy subjects. In this case, they observed that the expression of DQ570728 was significantly lower $(p<0.01)$ in asthma patients, while the expression of IL-4 was 
significantly higher $(p<0.01)$ than in healthy individuals. The altered expression of DQ570728 correlated inversely with the expression of IL-4 $(r=0.63)$ in asthma patients.

Another study analyzed the effect of the respiratory syncytial virus on exosomes composition in cells from the A549 cell line ${ }^{125}$. Their results showed that the content of the piRNAs increased in the cells infected with the virus $(34.7 \%)$ compared to control cells $(3.9 \%)$, demonstrating that the virus infection on A549 cells was associated with changes in the content of piRNAs in the exosomes.

Furthermore, a separate study utilized small airway epithelial cells exposed to a condensate of cigarette smoke to determine the small RNAs' composition in the extracellular vesicles ${ }^{126}$. The authors identified a decrease in the expression $(p<0.05)$ of five piRNAs (piR36705, piR37183, piR59260, piR36924, piR52900), and an increase in the expression $(p<0.05)$ of two piRNAs (piR31985, piR50603) concerning controls.

Similarly, Sundar et al. analyzed the extracellular vesicles' content in the plasma of smokers, patients with COPD, and non-smokers ${ }^{127}$. They selected the piRNAs that were expressed differentially $(p<0.01)$ to compare the three study groups. They identified three piRNAs (piR004153, piR020813, piR020450) in smokers and non-smokers; two piRNAs (piR012753, piR020813) in non-smokers and COPD patients; and four piRNAs (piR004153, piR020813, piR020450, piR016735) in smokers and COPD patients.

These studies demonstrate the differential expression of piRNAs in various diseases, although only one study performed a functional analysis that demonstrated the capacity of piRNAs to regulate the function of other genes. Therefore, this analysis is essential to understand piRNAs function in the development and progression of these diseases and the possibility of utilizing them as biomarkers and therapeutical targets $^{128,129}$. Unlike other ncRNAs-for example, the IncRNAs-piRNAs are not easily degraded and can efficiently pass through the cell membrane ${ }^{130}$. These characteristics allow piRNAs to be detected in samples that are easy to collect, such as serum, plasma, blood, and urine. One study demonstrated that the piR-57125, implicated in renal cancer, is readily detected in serum and plasma samples ${ }^{131}$.

\section{Perspectives}

As the discovery of piRNAs occurred a decade ago, many functions of the proteins that participate in their biogenesis are still unknown. However, we know that numerous factors participate in carrying out the transcriptional and post-transcriptional regulation of transposons and mRNA. The precise mechanisms involved in these functions are still under study, with most published reports focusing on attempts to elucidate them while setting aside analyses of the expression of these piRNAs in different cell lines under distinct types of stress, for example, components of environmental contamination in general.

In recent years, evidence has shown that many environmental contaminants alter the epigenome by modifying the state of DNA methylation, histones, or the expression of ncRNAs. Two of the main questions that need to be answered are how the action of different contaminants affects the expression of piRNAs and whether this expression has any functional importance for the diseases associated with prolonged exposure due to differential piRNAs expression. The answers to these questions will help understand better part of the complex mechanisms through which environmental contaminants generate changes in the genome.

Finally, it is essential to emphasize the potential use of piRNAs as therapeutic targets in various diseases, whether by blocking their expression or taking advantage of their characteristics through synthetic piRNAs capable of blocking protein synthesis by binding to mRNA. These possibilities represent another opportunity with potential applications in the fields of both biomedicine and clinical medicine.

\section{Ethical disclosures}

Protection of human and animal subjects. The authors declare that no experiments were performed on humans or animals for this study.

Confidentiality of data. The authors declare that they have followed the protocols of their work center on the publication of patient data.

Right to privacy and informed consent. The authors have obtained the written informed consent of the patients or subjects mentioned in the article. The corresponding author has this document.

\section{Conflicts of interest}

The authors declare no conflict of interest.

\section{Funding}

Project HIM/2016/006 SSA 1257. 


\section{Acknowledgments}

The authors wish to thank the Dirección de Investigación del Hospital Infantil de México Federico Gómez.

\section{References}

1. Iwasaki YW, Siomi MC, Siomi H. PIWI-interacting RNAs: its biogenesis and functions. Annu Rev Biochem. 2015;84:405-33.

2. Vázquez LMH. XVIII Jornadas Anuales Multidiciplinarias de la Sociedad Argentina de Biología. Codificar o no codificar: rol de RNA no codificantes en la fisiología y la patología. Argentina: Biocell; 2016. p. 93. Available from: https://www.biologia.org.ar.

3. Perkel JM. Visiting "noncodarnia." Biotechniques. 2013;54:301-4.

4. Ku HY, Lin H. PIWI proteins and their interactors in piRNA biogenesis, germline development and gene expression. Natl Sci Rev. 2014:1:205-18.

5. Kim VN, Han J, Siomi MC. Biogenesis of small RNAs in animals. Nat Rev Mol Cell Biol. 2009;10:126-39.

6. Azlan A, Dzaki N, Azzam G. Argonaute: the executor of small RNA function. J Genet Genomics. 2016;43:481-94.

7. Cox DN, Chao A, Baker J, Chang L, Qiao D, Lin H. A novel class of evolutionarily conserved genes defined by piwi are essential for stem cell self-renewal. Genes Dev. 1998;12:3715-27.

8. Aravin A, Gaidatzis D, Pfeffer S, Lagos-Quintana M, Landgraf P, lovino N, et al. A novel class of small RNAs bind to MILI protein in mouse testis. Nature. 2006;442:203-7.

9. Girard A, Sachidanandam R, Hannon GJ, Carmell MA. A germline-specific class of small RNAs binds mammalian Piwi proteins. Nature. 2006;442:199-202.

10. Grivna ST, Beyret E, Wang Z, Lin H. A novel class of small RNAs in mouse spermatogenic cells. Genes Dev. 2006;20:1709-14.

11. Watanabe T, Takeda A, Tsukiyama T, Mise K, Okuno T, Sasaki H, et al. Identification and characterization of two novel classes of small RNAs in the mouse germline: retrotransposon derived siRNAs oocytes and germline small RNAs in testes. Genes Dev. 2006;20:1732-43.

12. Gou LT, Kang JY, Dai $P$, Wang X, Li F, Zhao S, et al. Ubiquitination-deficient mutations in human piwi cause male infertility by impairing histone-to-protamine exchange during spermiogenesis. Cell. 2017;169:1090-104.e13.

13. Hasuwa H, Ishino K, Siomi H. Human PIWI (HIWI) is an azoospermia factor. Sci China Life Sci. 2018:61:348-50.

14. Wang X, Lv C, Guo Y, Yuan S. Mitochondria associated germinal structures in spermatogenesis: piRNA pathway regulation and beyond. Cells. 2020:9:399.

15. Kim VN. Small RNAs just got bigger: Piwi-interacting RNAs (piRNAs) in mammalian testes. Genes Dev. 2006;20:1993-7.

16. Le Thomas A, Rogers AK, Webster A, Marinov GK, Liao SE, Perkins EM, et al. Piwi induces piRNA-guided transcriptional silencing and establishment of a repressive chromatin state. Genes Dev. 2013;27:390-9.

17. Calcagno DQ, Mota ER, Moreira FC, de Sousa S.B.M, Burbano RR, Assumpçao PP. Role of PIWI Interacting RNA (piRNA) as Epigenetic Regulation. In: Patel V, Preedy V, editors. Handbook of nutrition, diet and epigenetics. Switzerland: Springer International Publishing; 2019. pp. 187209.

18. Krishnan P, Damaraju S. piRNAs in the Pathophysiology of Disease and Potential Clinical Applications. In: Mallick B, editor. Ago-driven non-coding RNAs. Codes to decode the therapeutics of diseases. London: Academic Press, Elsevier; 2019. pp. 335-56.

19. Sun T, Han X. The disease-related biological functions of PIWI-interacting RNAs (piRNAs) and underlying molecular mechanisms. ExRNA. 2019;1:21.

20. Ross RJ, Weiner MM, Lin H. PIWI proteins and PIWI-interacting RNAs in the soma. Nature. 2014;505:353-9.

21. Martinez VD, Vucic EA, Thu KL, Hubaux R, Enfield KSS, Pikor LA, et al Unique somatic and malignant expression patterns implicate PIWI-interacting RNAs in cancer type-specific biology. Sci Rep. 2015;5:10423.

22. Zhong F, Zhou N, Wu K, Guo Y, Tan W, Zhang H, et al. A snoRNA-derived piRNA interacts with human interleukin-4 pre-mRNA and induces its decay in nuclear exosomes. Nucleic Acids Res. 2015;43:10474-91.

23. Krishnan P, Ghosh S, Wang B, Heyns M, Graham K, Mackey JR, et al. Profiling of small nucleolar RNAs by next-generation sequencing: potential new players for breast cancer prognosis. PLoS One. 2016;11:e0162622.

24. Krishnan P, Ghosh B, Wang B, Heyns M, LiD, Mackey JR, et al. Genomic wide profiling of transfer RNAs and their role as novel prognostic markers for breast cancer. Sci Rep. 2016;6:32843.

25. Czech B, Hannon GJ. One loop to rule them all: the ping-pong cycle and piRNA-guided silencing. Trends Biochem Sci. 2016;41:324-37.

26. Zhang F, Wang J, Xu J, Zhang Z, Koppetsch BS, Schultz N, et al. UAP56 couples piRNA clusters to the perinuclear transposon silencing machinery. Cell. 2012;151:871-84.
27. Pippadpally S, Venkatesh T. Deciphering piRNA biogenesis through cytoplasmic granules, mitochondria and exosomes. Arch Biochem Biophys. 2020;695:108597.

28. Ipsaro JJ, Hace AD, Knott SR, Joshua-Tor L, Hannon GJ. The structural biochemistry of Zucchini implicates it as a nuclease in piRNA biogenesis. Nature. 2012;491:279-83

29. Nishimasu H, Ishizu H, Saito K, Fukuhara S, Kamatani MK, Bonnefond L, et al. Structure and function of Zucchini endoribonuclease in piRNA biogenesis. Nature. 2012;491:284-7.

30. Liu Y, Dou M, Song X, Dong Y, Liu S, Liu H, et al. The emerging role of the piRNA/piwi complex in cancer. Mol Cancer. 2019;18:123.

31. Murota $Y$, Ishizu H, Nakagawa S, Iwasaki YW, Shibata S, Kamatani MK, et al. $\mathrm{Yb}$ integrates piRNA intermediates and processing factors into perinuclear bodies to enhance piRISC assembly. Cell Rep. 2014;8:103-13.

32. Ozata DM, Gainetdinov I, Zoch A, O'Carroll D, Zamore PD. PIWI-interacting RNAs: small RNAs with big functions. Nat Rev Genet. 2019;20:89-108.

33. Vourekas A, Zheng Ke, Fu Q, Maragkakis M, Alexiou P, Ma J, et al. The RNA helicase MOV10L1 binds piRNA precursors to initiate piRNA processing. Genes Dev. 2015;29:617-29.

34. Zhang X, Yu L, Ye S, Xie J, Huang X, Zheng K, et al. MOV10L1 Binds RNA G-quadruplex in a structure-specific manner and resolves it more efficiently than MOV10. iScience. 2019;17:36-48.

35. Watanabe T, Chuma S, Yamamoto Y, Kuramochi-Miyagawa S, Took Y, Toyota A, et al. MitoPLD is a mitochondrial protein essential for nuage formation and piRNA biogenesis in the mouse germline. Dev Cell. 2010;20:364-75

36. Czech B, Preall JB, McGinn J, Hannon GJ. A transcriptome-wide RNAi screen in the Drosophila ovary reveals factors of the germline piRNA pathway. Mol Cell. 2013;50: 749-61.

37. Handler D, Meixner K, Pizka M, Lauss K, Schmied C, Gruber FS, et al. The genetic makeup of the Drosophila piRNA pathway. Mol Cell. 2013; 50:762-77.

38. Shiromoto $Y$, Kuramochi-Miyagawa S, Daiba A, Chuma S, Katanaya A, Katsuma A, et al. GPAT2, a mitochondrial outer membrane protein in piRNA biogenesis in germline stem cells. RNA. 2013;19:803-10.

39. Vagin VV, Yu Y, Jankowska A, Luo Y, Wasik KA, Malone CD, et al. Minotaur is critical for primary piRNA biogenesis. RNA. 2013;19:1064-77.

40. Olivieri D, Sentí KA, Subramanian S, Sachidanandam R, Brennecke J. The cochaperone shutdown defines a group of biogenesis factors essential for all piRNA populations in Drosophila. Mol Cell. 2012;47:954-69.

41. Preall JB, Czech B, Guzzardo PM, Muerdter F, Hannon GJ. Shutdown is a component of the Drosophila piRNA biogenesis machinery. RNA. 2012;18:1446-57.

42. Yamashiro H, Siomi MC. PIWI-interacting RNA in Drosophila: biogenesis, transposon regulation, and beyond. Chem Rev. 2018;118:4404-21.

43. Wu X, Pan $Y$, Fang $Y$, Zhang J, Xie M, Yang F, et al. The biogenesis and functions of piRNAs in human diseases. Mol Ther Nucleic Acids. 2020;21:108-20.

44. Handler D, Olivieri D, Novatchkova M, Gruber FS, Meixner K, Mechtler K, et al. A systematic analysis of Drosophila TUDOR domain-containing proteins identifies Vreteno and the Tdrd12 family as essential primary piRNA pathway factors. EMBO J. 2011;30:3977-93.

45. Zamparini AL, Davis MY, Malone CD, Vieira E, Zavadil J, Sachidanandam R, et al. Vreteno, a gonad-specific protein, is essential for germline development and primary piRNA biogenesis in Drosophila. Development. 2011:138:4039-50.

46. Izumi N, Shoji K, Suzuki Y, Katsuma S, Tomari Y. Zucchini consensus motifs determine the mechanism of pre-piRNA production. Nature. 2020;578:311-6

47. Saito K, Sakaguchi Y, Suzuki T, Suzuki T, Siomi H, Siomi MC. Pimet, the Drosophila homolog of HEN1, mediates 2'-O-methylation of Piwi-interacting RNAs at their 3' ends. Genes Dev. 2007;21:1603-8.

48. Horwich MD, Li C, Matranga C, Vagin V, Farley G, Wang P, et al. The Drosophila RNA methyltransferase, DmHen1, modifies germline piRNAs and single-stranded siRNAs in RISC. Curr Biol. 2007;17:1265-72.

49. Brennecke J, Aravin AA, Stark A, Dus M, Kellis M, Sachidanandam R, et al. Discrete small RNA-generating loci as master regulators of transposon activity in Drosophila. Cell. 2007;128:1089-103.

50. Mani SR, Juliano CE. Untangling the web: the diverse functions of the PIWI/piRNA pathway. Mol Reprod Dev. 2013;80:632-64.

51. Han BW, Wang W, Li C, Weng Z, Zamore PD. piRNA-guided transposon cleavage initializes Zucchini-dependent, phased piRNA production. Science. 2015;348:817-21.

52. Mohn F, Handler D, Brennecke J. piRNA-guided slicing specifies transcripts for Zucchini dependent, phased piRNA biogenesis. Science. 2015;348:812-7.

53. Senti KA, Jurczak D, Sachidanandam R, Brennecke J. piRNA-guided slicing of transposon transcripts enforces their transcriptional silencing via specifying the nuclear piRNA repertoire. Genes Dev. 2015;29:174762.

54. Wang W, Han BW, Tipping C, Tiafang GD, Zhang Z, Weng Z, et al. Slicing and binding by Ago3 or Aub trigger Piwi-bound piRNA production by distinct mechanisms. Mol Cell. 2015;59:819-30. 
55. Gainetdinov I, Colpan C, Arif A, Cecchini K, Zamore PD. A single mechanism of biogenesis, initiated and directed by PIWI proteins, explains piRNA production in most animals. Mol Cell. 2018;71:775-90.e5.

56. Czech B, Munafò M, Ciabrelli F, Eastwood EL, Fabry MH, Kneuss E, et al. piRNA-guided genome defense: from biogenesis to silencing. Annu Rev Genet. 2018;52:131-57.

57. Sato K, Siomi MC. The piRNA pathway in Drosophila ovarian germ and somatic cells. Proc Jpn Acad Ser B Phys Biol Sci. 2020;96:32-42.

58. Ng KW, Anderson C, Marshall EA, Minatel BC, Enfield KS, Saprunoff HL, et al. Piwi-interacting RNAs in cancer: emerging functions and clinical utility. Mol Cancer. 2016;15:5.

59. Klenov MS, Sokolova OA, Yakushev EY, Stolyarenko AD, Mikhaleva EA, Lavrov SA, et al. Separation of stem cell maintenance and transposon silencing functions of Piwi protein. Proc Natl Acad Sci USA. 2011; 108:18760-5.

60. Sienski G, Dönertas D, Brennecke J. Transcriptional silencing transposons by Piwi and Maelstrom and its impact on chromatin state and gene expression. Cell. 2012:151:964-80.

61. Weick EM, Sarkies P, Silva N, Chen RA, Moss SM, Cording AC, et al. PRDE-1 is a nuclear factor essential for the biogenesis of Ruby motif-dependent piRNAs in C. elegans. Genes Dev. 2014;28:783-96.

62. Dönertas D, Sienski G, Brennecke J. Drosophila Gtsf1 is an essentia component of the Piwi-mediated transcriptional silencing complex. Genes Dev. 2013;27:1693-705.

63. Muerdter F, Guzzardo PM, Gillis J, Luo Y, Yu Y, Chen C, et al. A genome-wide RNAi screen draws a genetic framework for transposon control and primary piRNA biogenesis in Drosophila. Mol Cell. 2013; 50:736-48.

64. Sienski G, Batki J, Sentí KA, Dönertas D, Tirian L, Meixner K, et al. Silencio/CG9754 connects the Piwi-piRNA complex to the cellular heterochromatin machinery. Genes Dev. 2015;29:2258-71.

65. Yu Y, Gu J, Jin Y, Luo Y, Preall JB, Ma J, et al. Panoramix enforces piRNA-dependent cotranscriptional silencing. Science. 2015;350:339-42.

66. Ninova M, Chen YA, Godneeva B, Rogers AK, Luo Y, Fejes Tóth K, et al. Su(var)2-10 and the SUMO pathway link piRNA-guided target recognition to chromatin silencing. Mol Cell. 2020;77:556-70.e6.

67. Huang XA, Yin H, Sweeney S, Raha D, Snyder M, Lin H. A major epigenetic programming mechanism guided by piRNAs. Dev Cell. 2013;24:502-16

68. Murano K, Iwasaki YW, Ishizu H, Mashiko A, Shibuya A, Kondo S, et al. Nuclear RNA export factor variant initiates piRNA-guided cotranscriptional silencing. EMBO J. 2019;38:e102870.

69. Yang Z, Chen KM, Pandey RR, Homolka D, Reuter M, Janeiro BK, et al. PIWI slicing and EXD1 drive biogenesis of nuclear piRNAs from cytosolic targets of the mouse piRNA pathway. Mol Cell. 2016; 61:138-52.

70. Matsumoto N, Sato K, Nishimasu H, Namba Y, Miyakubi K, Dohmae N, et al. Crystal structure and activity of the endoribonuclease domain of the piRNA pathway factor Maelstrom. Cell Rep. 2015;11:366-75.

71. Aravin AA, Sachidanandam R, Bourc'his D, Schaefer C, Pezic D, Toth $\mathrm{KF}$, et al. A piRNA pathway primed by individual transposons is linked to de novo DNA methylation in mice. Mol Cell. 2008;31:785-99.

72. Kuramochi-Miyagawa S, Watanabe T, Gotoh K, Totoki Y, Toyoda A, Ikawa $\mathrm{M}$, et al. DNA methylation of retrotransposon genes is regulated by Piwi family members MILI and MIWI2 in murine fetal testes. Genes Dev. 2008:22:908-17.

73. Li Z, Tang X, Shen EZ. How mammalian piRNAs instruct de novo DNA methylation of transposons. Signal Transduct Target Ther. 2020;5:190.

74. De Fazio S, Bartonicek N, Di Giacomo M, Abreu-Goodger C, Sankar A, Funaya C, et al. The endonuclease activity of Mili fuels piRNA amplification that silences LINE1 elements. Nature. 2011;480:259-63.

75. Manakov SA, Pezic D, Marinos GK, Pastor WA, Sachidanandam R, Aravin AA. MIWI2 and MILI have differential effects on piRNA biogenesis and DNA methylation. Cell Rep. 2015;12:1234-43.

76. Zoch A, Auchynnikava T, Berrens RV, Kabayama Y, Schöpp T, Heep M, et al. SPOCD1 is an essential executor of piRNA-directed de novo DNA methylation. Nature. 2020:584:635-9.

77. Zhang P, Kang JY, Gou LT, Wang J, Xue Y, Skogerboe G, et al. MIWI and piRNA-mediated cleavage of messenger RNAs in mouse testes. Cell Res. 2015;25:193-207.

78. Peng L, Song L, Liu C, Lv X, Li X, Jie J, et al. piR-55490 inhibits the growth of lung carcinoma by suppressing mTOR signaling. Tumour Biol. 2016:37:2749-56.

79. Liu X, Zheng J, Xue Y, Yu H, Gong W, Wang P, et al. PIWIL3/OIP5-AS1/ miR-367-3p/CEBPA feedback loop regulates the biological behavior of glioma cells. Theranostics. 2018;8:1084-105.

80. Tan L, Mai D, Zhang B, Jiang X, Zhang J, Bai R, et al. PIWI-interacting RNA-36712 restrains breast cancer progression and chemoresistance by interaction with SEPW1 pseudogene SEPW1P RNA. Mol Cancer. 2019;18:9.

81. Rojas-Ríos P, Simonelig M. piRNAs and PIWI proteins: regulators of gene expression in development and stem cells. Development. 2018;145:dev161786.
82. Rouget C, Papin C, Boureux A, Meunier AC, Franco B, Robine N, et al. Maternal mRNA deadenylation and decay by the piRNA pathway in the early Drosophila embryo. Nature. 2010;467:1128-32.

83. Nagao A, Mituyama T, Huang H, Chen D, Siomi MC, Siomi H. Biogenesis pathways of piRNAs loaded onto AGO3 in the Drosophila testis. RNA. 2010;16:2503-15.

84. Lim AK, Lorthongpanich C, Chew TG, Tan CW, Shue YT, Balu S, et al. The nuage mediates retrotransposon silencing in mouse primordial ovarian follicles. Development. 2013;140:3819-25.

85. Kiuchi T, Koga H, Kawamoto M, Shoji K, Sakai H, Arai Y, et al. A single female-specific piRNA is the primary determiner of sex in the silkworm. Nature. 2014;509:633-6.

86. Gou LT, Dai P, Yang JH, Xue Y, Hu YP, Zhou Y, et al. Pachytene piRNAs instruct massive mRNA elimination during late spermiogenesis. Cell Res. 2014:24:680-700.

87. Barckmann B, Pierson S, Dufourt J, Papin C, Armenise C, Port F, et al. Aubergine iCLIP reveals piRNA-dependent decay of mRNAs involved in germ cell development in the early embryo. Cell Rep. 2015;12:1205-16.

88. Goh WS, Falciatori I, Tam OH, Burgess R, Meikar O, Kotaja N, et al. piRNA-directed cleavage of meiotic transcripts regulates spermatogenesis. Genes Dev. 2015;29:1032-44.

89. Watanabe T, Cheng EC, Zhong M, Lin H. Retrotransposons and pseudogenes regulate mRNAs and IncRNAs via the piRNA pathway in the germline. Genome Res. 2015;25:368-80.

90. Gebert $D$, Ketting RF, Zischler H, Rosenkranz D. piRNAs from pig testis provide evidence for a conserved role of the Piwi pathway in post-transcriptional gene regulation in mammals. PLoS One. 2015;10:e0124860

91. Kotelnikov RN, Klenov MS, Rozovsky YM, Olenina LV, Kibanov MV, Gvozdev VA. Peculiarities of piRNA-mediated post-transcriptional silencing of Stellate repeats in testes of Drosophila melanogaster. Nucleic Acids Res. 2009;37:3254-63.

92. Reuter M, Berninger P, Chuma S, Shah H, Hosokawa M, Funaya C, et al. Miwi catalysis is required for piRNA amplification-independent LINE1transposon silencing. Nature. 2011;480:264-7.

93. Liu L, Qi H, Wnag J, Lin H. PAPI, a novel TUDOR-domain protein complexes with AGO3, ME31B and TRIAL in the nuage to silence transposition. Development. 2011:138:1863-73.

94. Tanaka T, Hosokawa M, Vagin VV, Reuter M, Hayashi E, Mochizuki AL, et al. Tudor domain containing 7 (Tdrd7) is essential for dynamic ribonucleoprotein (RNP) remodeling of chromatoid bodies during spermatogenesis. Proc Natl Acad Sci USA. 2011;108:10579-84.

95. Lim AK, Tao L, Kai T. piRNAs mediate post-transcriptional retroelement silencing and localization to pi-bodies in the Drosophila germline. J Cell Biol. 2009:186:333-42.

96. Aravin AA, van der Heijden GW, Castañeda J, Vagin VV, Hannon GJ, Bortvin A. Cytoplasmic compartmentalization of the fetal piRNA pathway in mice. PLoS Genet. 2009:5:e1000764.

97. Shoji M, Tanaka T, Hosokawa M, Reuter M, Stark A, Kato Y, et al. The TDRD9-MIWI2 complex is essential for piRNA-mediated retrotransposon silencing in the mouse male germline. Dev Cell. 2009;17:775-87.

98. Saxe JP, Chen M, Zhao H, Lin H. Tdrkh is essential for spermatogenesis and participates in primary piRNA biogenesis in the germline. EMBO J. 2013;32:1869-85.

99. Huang G, Hu H, Xue X, Shen S, Gao E, Guo G, et al. Altered expression of piRNAs and their relation with clinicopathologic features of breast cancer. Clin Transl Oncol. 2013;15:563-8.

100. Cui L, Lou Y, Zhang X, Zhou H, Deng H, Song H, et al. Detection of circulating tumor cells in peripheral blood from patients with gastric cancer using piRNAs as markers. Clin Biochem. 2011;44:1050-7.

101. Lin X, Xia Y, Hu D, Mao Q, Yu Z, Zhang H, et al. Transcriptome-wide piRNA profiling in human gastric cancer. Oncol Rep. 2019;41:308999 .

102. Li D, Luo $Y$, Gao $Y$, Yang $Y$, Wang $Y, X u Y$, et al. piR-651 promotes tumor formation in non-small cell lung carcinoma through the upregulation of cyclin D1 and CDK4. Int J Mol Med. 2016:38:927-36.

103. Reeves ME, Firek M, Jliedi A, Amaar YG. Identification and characterization of RASSF1C piRNA target genes in lung cancer cells. Oncotarget. 2017:8:34268-82.

104. Öner Ç, Turgut CD, Çolar E. Estrogen and androgen hormone levels modulate the expression of PIWI-interacting RNA in prostate and breast cancer. PLOS ONE. 2016:11:e0159044.

105. Yin J, Qi W, Ji CG, Zhang DX, Xie XL, Ding Q, et al. Small RNA sequencing revealed aberrant piRNA expression profiles in colorectal cancer. Oncol Rep. 2019;42:263-72.

106. Weng W, Liu N, Toiyama Y, Kusunoki M, Nagasaka T, Fujiwara T, et al. Novel evidence for a PIWI-interacting RNA (piRNA) as an oncogenic mediator of disease progression, and a potential prognostic biomarker in colorectal cancer. Mol Cancer. 2018:17:16.

107. Li Y, Wu X, Gao H, Jin JM, Li AX, Kim YS, et al. Piwi-interacting RNAs (piRNAs) are dysregulated in renal cell carcinoma and associated with tumor metastasis and cancer-specific survival. Mol Med. 2015;21:381-8. 
108. Zhao C, Tolkach $Y$, Schmidt D, Toma M, Muders MH, Kristiansen G, et al. Mitochondrial PIWI-interacting RNAs are novel biomarkers for clear cell renal cell carcinoma. World J Urol. 2019;37:1639-47.

109. Chu H, Hui G, Yuan L, Shi D, Wang Y, Du M, et al. Identification of novel piRNAs in bladder cancer. Cancer Lett. 2015;356:561-7.

110. Yan H, Wu QL, Sun CY, Ai LS, Deng J, Zhang L, et al. piRNA 823 contributes to tumorigenesis by regulating de novo DNA methylation and angiogenesis in multiple myeloma. Leukemia. 2015;29:196-206.

111. Yue H, Yun Y, Gao R, Li G, Sang N. Winter polycyclic aromatic hydrocarbon-bound particulate matter from peri-urban North China promotes lung cancer cell metastasis. Environ Sci Technol. 2015;49:14484-93.

112. Xu Y, Wu J, Peng X, Yang T, Liu M, Chen L, et al. LncRNA LINC00341 mediates $\mathrm{PM}_{25}$-induced cell cycle arrest in human bronchial epithelia cells. Toxicol Lett. 2017;276:1-10.

113. Huang $Q$, Chi Y, Deng J, Liu Y, Lu Y, Chen J, et al. Fine particulate matter 2.5 exerted its toxicological effect by regulating a new layer, long non-coding RNA. Sci Rep. 2017;7:9392.

114. Lin $H$, Zhang $X$, Feng $N$, Wang $R$, Zhang $W$, Deng $X$, et al. LncRNA LCPAT1 mediates smoking/particulate matter 2.5-induced cell autophagy and epithelial-mesenchymal transition in lung cancer cells via RCC2. Cell Physiol Biochem. 2018;47:1244-58.

115. Wang $Y$, Tang $M$. Integrative analysis of mRNAs, miRNAs and IncRNAs in urban particulate matter SRM 1648a-treated EA.hy926 human endothelial cells. Chemosphere. 2019;233:711-23.

116. Li X, Zheng M, Pu J, Zhou Y, Hong W, Fu X, et al. Identification of abnormally expressed IncRNAs induced by PM2.5 in human bronchial epithelial cells. Biosci Rep. 2018;38:BSR20171577.

117. Tan Y, Wang Y, Zou Y, Zhou C, Yi Y, Ling Y, et al. LncRNA LOC101927514 regulates $\mathrm{PM} 2.5$-driven inflammation in human bronchial epithelial cells through binding p-STAT3 protein. Toxicol Lett. 2020;319:119-28.

118. Quezada-Maldonado EM, Sánchez-Pérez Y, Chirino YI, Vaca-Paniagua F, García-Cuellar CM. miRNAs deregulation in lung cells exposed to airborne particulate matter $\left(\mathrm{PM}_{10}\right)$ is associated with pathways deregulated in lung tumors. Environ Pollut. 2018;241:351-8.

119. He X, Chen Y, Zhang C, Gong W, Zhang X, Nie S. Polycyclic aromatic hydrocarbons from particulate matter $2.5\left(\mathrm{PM}_{25}\right)$ in polluted air changes miRNA profile related to cardiovascular disease. Med Sci Monit. 2018;24:5925-34.
120. Hou T, Liao J, Zhang C, Sun C, Li X, Wang G. Elevated expression of miR-146, miR-139 and miR-340 involved in regulating Th1/Th2 balance with acute exposure of fine particulate matter in mice. Int Immunopharmacol. 2018;54:68-77.

121. Ning J, Li P, Zhang B, Han B, Su X, Wang Q, et al. miRNAs deregulation in serum of mice is associated with lung cancer-related pathway deregulation induced by PM2.5. Environ Pollut. 2019;254:112875.

122. Li J, Wang T, Wang Y, Xu M, Zhang L, Li X, et al. Particulate matter air pollution and the expression of microRNAs and pro-inflammatory genes: association and mediation among children in Jinan, China. J Hazard Mater. 2020:389:121843.

123. Alexandrova E, Miglino N, Hashim A, Nassa G, Stellato C, Tamm M, et al. Small RNA profiling reveals deregulated phosphatase and tensin homolog (PTEN)/phosphoinositide 3-kinase (PI3K)/Akt pathway in bronchial smoohuscle cells from asthmatic patients. J Allergy Clin Immunol. 2016;137:58-67.

124. Zhong F, Zhou N, Wu K, Guo Y, Tan W, Zhang H, et al. A SnoRNA-derived piRNA interacts with human interleukin-4 pre-mRNA and induces its decay in nuclear exosomes. Nucleic Acids Res. 2015;43:10474-91.

125. Chahar HS, Corsello T, Kudlicki AS, Komaravelli N, Casola A. Respiratory syncytial virus infection changes cargo composition of exosome released from airway epithelial cells. Sci Rep. 2018;8:387.

126. Corsello T, Kudlicki AS, Garofalo RP, Casola A. Cigarette smoke condensate exposure changes RNA content of extracellular vesicles released from small airway epithelial cells. Cells. 2019;8:1652.

127. Sundar IK, Li D, Rahman I. Small RNA-sequence analysis of plasma-derived extracellular vesicle miRNAs in smokers and patients with chronic obstructive pulmonary disease as circulating biomarkers. J Extracell Vesicles. 2019;8:1684816.

128. Liu Y. MicroRNAs and PIWI-interacting RNAs in oncology. Oncol Lett. 2016;12:2289-92.

129. Guo B, Li D, Du L, Zhu X. piRNAs: biogenesis and their potential roles in cancer. Cancer Metastasis Rev. 2020;39:567-75.

130. Mei Y, Clark D, Mao L. Novel dimensions of piRNAs in cancer. Cance Lett. 2013:336:46-52

131. Yang $X$, Cheng $Y$, Lu Q, Wei J, Yang H, Gu M. Detection of stably expressed piRNAs in human blood. Int J Clin Exp Med. 2015;8:13353-8. 